\title{
The impact of Catechesis among grade 12 Non-Catholic and Non-Christian students of University of Santo Tomas senior high school
}

Quimson, Leonardo O., Jr.

University of Santo Tomas, Philippines (loquimson@ust.edu.ph; leonardo_quimson@dlsu.edu.ph)

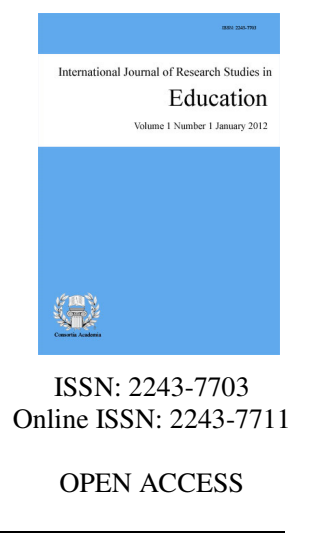

Received: 9 September 2020
Available Online: 4 December 2020

Revised: 16 October 2020

Accepted: 10 November 2020 DOI: $10.5861 /$ ijrse. 2020.5725

\section{Abstract}

Catechesis or Religious Education is the act or process of teaching the faith to make the Gospel of Jesus be known to all people. As the Lord commissioned the apostles during the mission mandate to "go and proclaim the good news to all nations and baptizing them in the name of the Father, and of the Son and of the Holy Spirit", it clearly shows the very vital role and mission of the Church to evangelize and make disciples of Christ. With this great responsibility, the Church, through the help of the Catholic schools, must proclaim the Christian faith to all, not only the Catholics and Christians, but to all people, regardless of faith and culture. The message of Christ's teaching is rooted in love, which is common among all religions and beliefs. In celebrating this Year of Ecumenism, Interreligious dialogue and Indigenous cultures, the researcher conducted a study and tried to find out the impact or effect of catechesis or religious education to the students of the University of Santo Tomas Senior High School who are non-Catholics and non-Christians in their faith life. The respondents of this study are the students from the Grade 12 level under the Science, Technology, Engineering and Mathematics (STEM) strand. Moreover, the researcher used the "mixed method" of descriptive method through survey questionnaires in order to gather and analyze data. The results of the study would be a great help for catechists and religious educators to know if there is an outcome or impact in teaching the Christian faith to people who have different faiths and culture. At the end, this research would also suggest some ways in order to make catechesis more effective, holistic and inclusive in nurturing one's relationship with God and promote dialogue, harmony and understanding among different faiths especially for the strengthening of the mission of Catholic Schools to make known and echo the message of Jesus.

Keywords: Catechesis; religious education; Ecumenism; interreligious dialogue; Catholic school 


\section{The impact of Catechesis among grade 12 Non-Catholic and Non-Christian students of University of Santo Tomas senior high school}

\section{Introduction}

This research will present first some insights, ideas, and opinions regarding catechesis: its nature and meaning as well as its aims, goals and basic contents or aspects. After these, the study will show the relevance of the mission of catholic schools in teaching catechesis as an evangelizing arm of the Church to all people: including those students or learners who are non-Catholics or non-Christians. Following the mandate of Jesus Christ, before He ascended into heaven, He told to His disciples to "Go, therefore, and make disciples of all nations, baptize them in the name of the Father, and of the Son, and of the Holy Spirit, teaching them to observe all that I have commanded you. And behold, I am with you always, until the end of the age" (Matthew 28:19-20). This immense mandate given by the Lord to the apostles brings forth the foundation of the Church and the initial proclamation of the faith. After His Paschal mystery, Jesus Christ "together with God the Father sent the Holy Spirit in order that He might accomplish from within His salvific work and that He might animate the apostles to continue His mission to the world" (GDC, 1997, \#34). These very words coming from Jesus is the seed of catechesis.

\subsection{Catechesis: Its nature and meaning}

What is catechesis? Why is it essential in the Christian faith? According to Fr. Braulio Peña, O.P. (1982), the word catechesis came from the Greek word "katechizein" which means "to transmit, to deliver, to pass." Catechesis is a term which means "the practice or actual transmission of the message of Jesus Christ." (Peña, 1982, p.9) St. Pope John Paul II (1979) also explained in his apostolic exhortation "Catechesi Tradendae" that catechesis as "the education of faith, especially the teaching of the Christian doctrine passed on in a systematic and organic way, with a view to initiating the hearers into fullness of Christian life" (\#18). Moreover, it is also defined by the Synod of Bishops (1977) as "the activity by which the Word of God is constantly spread in a living and effective way, and which leading to a deeper relationship with Jesus Christ, both His Person and His saving message, consists in an ordered and progressive education in the faith, joined to a continuous process or maturing in the same faith" (\#1).

Catechesis also "lays the groundwork for the building of the faith...the essential ecclesial service for the understanding of the mission mandate of our Lord Jesus Christ...It is the process of transmitting the Good News, as the Christian community received it, understands it, celebrates it, lives it and communicates it in various ways" (NCDP, 2007, \#100 \& 102).

The Sacred Congregation for the Clergy, in its document entitled the "General Directory for Catechesis" (1997) developed the nature of catechesis as "a complete and organized formation of the faith and an apprenticeship of the whole Christian living... a vital and necessary formation centered on the experience of Christ" (\#67). Therefore, "the very essence and heart of catechesis is no other than the Person of Jesus, the only begotten Son of the Father who suffered and died for all people and who now, after rising from the dead, is living with us eternally" (CCC, 1994, \#426). Jesus wants all Christians to receive the Gospel and have fullness of life, as St. Irenaeus of Lyons would tell, "The glory of God is a human being fully alive" (Barron, 2006). A person who is being catechized has "a time of formation and apprenticeship in the entire Christian life" (GDC, 1997, \#63). Catechesis is essential in the mission of the Church because it is the "first element of renewed evangelization" (PCP II, 1992, \#156). And as "integral part of evangelization, catechesis aims to make all people's faith become alive, active and conscious through the light of instruction" (NNCDP, 2007, \#102). 


\subsection{Catechesis: Its aims and goals}

Catechesis has its primary aim in "bringing the totality of the Christian message of Good News in order for its hearers to become living witnesses of Jesus on their daily life in the world... Maturing in the faith refers to the ongoing growth in the Christian faith that permeates each part of one's personal and communal life" (Natividad, 2018, p. 29). In other words, catechesis aims that every Christian must have an intimate relationship with Jesus Christ rooted in faith that is known, lived, and celebrated. The Second Plenary Council of the Philippines (PCP II, 1992) gave emphasis on the importance of catechesis as the "most important area of renewal in the pastoral ministry of the Philippine Church... showing its significant relation to social apostolate and worship or prayer life" (\#183-184). The said Council emphasizes in its acts and decrees the strong emphasis on renewal in the Christian faith. With its "Renewed Integral Evangelization", the council "commits the local Churches and even the Catholic and Parochial Schools to the following movements namely "renewed catechesis, renewed social apostolate and renewed worship". Through these three ways or actions, the Church in the Philippines also sets Her goals, new methods, zeal, and expressions in proclaiming the faith as well as the process of inculturation to life situation or human experience so that learners will be formed holistically and attain fullness of life" (as quoted by Peña, p. 117).

Renewed Catechesis is the "priority that must be received for without education and maturing in faith, social apostolate will just become activism and worship becomes superstition or magical mentality. Furthermore, learning the faith without social apostolate will lessen the Christian witnessing and social transformation, and without prayer and worship, catechesis will be indoctrination. Lastly, the social apostolate without prayer will lessen its source of strength or vigor, while worship without social action will make prayer divorced from witnessing. With these, genuine renewal will take effect if all the three areas are interrelated, resulting to holistic or integral formation of the faith" (PCP II, 1992, \#182-185).

In response to PCP II's call for renewed catechesis, social apostolate and worship, the Catholic Bishops Conference of the Philippines or CBCP, with the approval of the Holy See, promulgated the official national catechism entitled "Catechism for Filipino Catholics" or CFC (1997) which offered the "Three Essential Dimensions of Faith" in relation to the vision of PCP II's renewed integral evangelization. The Filipino bishops stated that: “...Christian faith must touch every part of us, our minds (believing), our wills (doing), and our hearts (entrusting). Faith involves our basic convictions as Christians... Faith, then, is believing and having personal understanding of Christ. But besides believing, faith is also doing, a commitment to follow God's will... Lastly, beyond believing and doing, faith is also entrusting into the hands of God. Faith, then, is from the heart... living and growing through prayer and worship" (\#128-133).

This is also visible to what Thomas Groome (2011) presented on his reflection on the goal of catechesis as holistic Christian faith and life in the way of "Head, Heart and Hands". He said: "Jesus presented faith as a total way of life engaging people's heads, hearts and hands... and so to be His disciple means to follow His ways, what He modelled and made possible. First, the way of Head demands discipleship of faith seeking understanding and faith with personal conviction, maintained by learning and research, by probing and reflecting, by discerning and deciding, all toward spiritual wisdom of life. Second, the way of the Heart demands discipleship of correct relationships and true desires, community making, inclusion and hospitality, trusting God's love, and prayer and worship. Lastly, the way of the Hands demands discipleship of charity, justice, peacemaking, simplicity, honesty, healing and atonement" (p. 111).

This really shows that catechesis or teaching the faith is not only limited on the formation of knowledge but "the heart of catechesis is a vision of a person formed for a life of service for God and for His people" (Rymarz, 2011, p. 5). But to have a deep encounter and renewed relationship with the Lord, a person must open first his heart and have "conversion" as a beginning of renewed being. He or she must "turn away from sin and turns to the Lord and undergoes "metanoia" or change of mind and heart." (PCP II, 1992, \#156) Thus, the role of catechesis is to be an "essential component of the Church's mission of evangelization which is to deepen the 
faith that evangelization invokes... The role of the catechists and religious educators is to echo not personal opinions or attitudes, but the message of Christ, the Lord's self-disclosure of love or revelation to the whole world" (Natividad, 2018, pp. 25-26). To catechize also means "to make all people know and practice the teachings of Christianity" (Ortiz, n. d., p. 7). Catechesis "builds up God's Kingdom of justice, peace and love that is so central to the teaching of Jesus... the Catechist of the Kingdom of God" (Groome, 2011, p. 105).

Furthermore, Fr. Joseph Roche, S.J. (2008) shared in his book entitled "Practical Catechesis: The Christian Faith as a Way of Life" that there are three goals of catechesis or religious education. The first is the "goal of Christian Education or catechesis is conceived primarily in terms of formation and transformation- beyond head level faith. Catechesis therefore is not only about "banking" necessary doctrines or teachings of the faith, rather, it must go beyond our learning and radiate its fruits through active involvement or social action and celebration of faith in worship. Secondly, catechesis has its "ecclesial dimension" to strengthen the Church as an indispensable setting for Catholic education. With this, Fr. Roche shows the role of the Church as "School of Christ and Christian discipleship" She is called to perform the Good News through following the way of Jesus. Lastly, the goal of catechesis is to "foster critical reflection on the religious experiences to help ground one's identity as Christian. But this is not only about reflecting one's experiences, but it must be connected to the deposits of faith, namely Sacred Scriptures and Tradition which makes it a distinct function of catechesis, the interplay of the Word of God and human experience in connection to the teachings of the Church" (pp. 30-33).

Meanwhile, the New National Catechetical Directory for the Philippines or NNCDP (2007) confirmed specific goals of catechesis. First, is to "develop understanding of the truths of the Catholic faith taken from the fundamental sources of faith- Sacred Scripture, Tradition and the Church's teaching arm, the Magisterium... to love and appreciate God's living Word and the teachings or doctrines of the Catholic faith." Second, the goal of catechesis is "to educate the catechized regarding the essential principles and practice of Christian Morality...through the Commandments, the concrete norms of love." Third, the specific goal of catechesis is "to instruct the Catholic faithful on how to pray and actively participate in the liturgy of the Church... in the sacraments particularly in the Eucharist, to receive Christ's life-sustaining gift of Himself, the Risen Lord whom we encounter." Another goal of catechesis is "to develop a sense of belongingness and commitment to serve as active members in the Church community...best exemplified through Basic Ecclesial Communities or BEC's." Lastly, the fifth goal of catechesis is "to make the catechized grow in incarnating the Christian faith in attitudes and values in daily living, at the same time, interpreting and relating their daily life experiences in the light of the Gospel... to be able to discern the daily events and choices of one's life in the light of faith... discovering how God works in your life" (\# 124- 131).

\subsection{The mission of the Catholic Schools in Catechesis}

According to the Sacred Congregation for Catholic Education (1977), in the document entitled "The Catholic School", the Church explains the Catholic School's fundamental mission of that "forms part of the Church's saving mission, especially for education of faith... It is precisely in the Good News of Jesus, taking root in the minds and lives of people, that the Catholic school finds its meaning as it comes to terms with the educational conditions of the times" (\# 9). Catholic Schools are among "the most essential and effective avenues of evangelization of the Church... and it should therefore reaffirm evangelization as its primary goal for education" (PCP II, 1992, \#623 \& 637).

One concrete example of this reality of essential relation between the Church and the Catholic Schools is the action of the Third Plenary Council of Baltimore in 1884, where in the assembled U.S. Catholic bishops decreed that every parish must have a parochial school because they believed that this is necessary in preserving the faith of the people" (Groome, 2011, p.234). That is why "the special quality of the Catholic school, the core reason for it, the basis why Catholic parents prefer it, is specifically the value of the religious instruction included in the education of the students" (as quoted from St. Pope John Paul II by Peña, p. 277). 
The goal of Catholic schools is to "enable each baptized person to live to the full their baptismal dignity and calling... to equip them to take an active part in the transformation of the society and the realization of a more just and peaceful world. A Catholic school must be a graced atmosphere in which the Person of Jesus Christ is innermost, and the wonders of the Good News were shared, and young people are enabled to understand and value the relationship between culture and faith; between faith and daily living" (Hawker \& Bowman, 1984, p. 1). This gives the students at Catholic schools on their "right to find out with truth and certainty the faith to which they belong, this right to see Christ and the saving message He proclaimed cannot be disregarded" (GDC, 1997, \#74). This also shows that Catholic schools are given this essential mission to be an evangelizing arm of the Church for they must "give integral or holistic education which is a right for every student or learner, and it will respond later on to all his or her needs as a human person" (Sacred Congregation for Catholic Education, 1983, \#3).

In the Declaration on Christian Education or Gravissimum Educationis (1965), St. Pope Paul VI discussed that, "the Sacred Ecumenical Council has measured with care how exceptionally vital education is in the life of human beings and how its influence ever grows in the social development of this age... To fulfil the directive, She has received from Her Creator of proclaiming the mystery of salvation to all people and of restoring all things in Jesus, Holy Mother Church must be concern with the whole living of a person, even the secular part of it insofar as it has a bearing on Her divine calling (Introduction). A school is not only a place where a learner is given a choice of intellectual values, but "a place where one has presented a group of values which are lived actively.

The school must be a society whose values are communicated through interpersonal and honest relationships of its members and through both individual and corporative faithfulness to the viewpoint on life that permeates the school" (TCS, 1977, \# 32). With this mission entrusted to the Catholic school to be holistic formators of faith and life for all people not only for Catholics, the Church Fathers of the Second Vatican Council "invited our brothers and sisters who are non-Catholics and non-Christians to send their children to Catholic schools" (Donlevy, 2007, p. 295). St. Pope Paul VI in his Declaration on Christian Education or "Gravissimum Educationis" (1965) expressed, "The Church thinks very clear to Her heart the Catholic Schools... which are attended also by students who are non-Catholics... This council of the Church sincerely asks pastors and all faithful to spare no sacrifice in helping Catholic schools fulfil Her mission... especially in caring for the desires of those ... who are unfamiliar to the faith (\#9).

\section{Methodology}

This study will use the descriptive method of research following the "mixed method" as its design. The researcher will use the "survey method" in descriptive research. After participants answer the questions, the researcher will describe the responses given. For the survey to be both reliable and convincing, it is significant that the questions are constructed properly. Moreover, this study focuses on acquiring responses among Grade 12 students on the previous academic year 2018-2019 from the Science, Technology, Engineering and Mathematics (STEM) strand of the UST Senior High School. Founded in 2016, the UST Senior High School is the youngest Basic Education Department in the said University. The researcher, through the help of the class president and the secretary of each class, collate the number of respondents in each class. There are 30 respondents in this study ranging from age 17-18 years old. All of them already graduated last June 2019 and completed all the three courses in the Christian Living Education namely Salvation History, Christology and the Church and the Sacraments which are grounded from the Sacred Scriptures, the Church teachings such as the Catechism of the Catholic Church and the Catechism for Filipino Catholics.

\section{Presentation, interpretation, and analysis of data}

The researcher tallied the frequency of responses per score in each item. Afterwards, the researcher arranged the computed mean from highest to lowest. Below is the table showing the computed average mean in each item 
Quimson, L. O., Jr.

of the questionnaire and its interpretation and rank:

Table 1

Descriptive of responses

\begin{tabular}{lccc}
\hline \multicolumn{1}{c}{ Factors/Items } & Mean & Interpretation & Rank \\
\hline The subject "Fundamentals of Faith or FunFaith” ... & & & \\
Teaches me to know more about Jesus Christ. & 3.80 & Strongly Agree & 3 \\
Helps me to understand the teachings of the Catholic Church. & 3.76 & Strongly Agree & 4 \\
Makes me aware of the different religious practices of the Catholics. & 3.73 & Strongly Agree & 5 \\
Deepens my realization that my belief has also similarities in the Catholic faith. & 3.60 & Strongly Agree & 6 \\
Develops in me good relationships with people of other religion. & 3.56 & Strongly Agree & 7 \\
Instills in me good attitudes and values in life. & 3.83 & Strongly Agree & 2 \\
Helps me to respect the beliefs of others. & 3.86 & Strongly Agree & 1 \\
Guides me on how to express my faith in God. & 3.43 & Strongly Agree & 8 \\
Makes me feel that I belong even if I am not a Catholic. & 3.40 & Strongly Agree & 9 \\
Helps me improve my prayer or spiritual life. & 3.26 & Strongly Agree & 10 \\
\hline
\end{tabular}

Looking at the results of the quantitative survey, the first three highest items, describes what "Fundamentals of Faith" subject had an impact among the non-Catholics and non-Christian respondents are the following:

The subject "Fundamentals of Faith" helps me to respect the beliefs of others. (3.86)

$>\quad$ The subject "Fundamentals of Faith" instills in me good attitudes and values in life. (3.83)

$>$ The subject "Fundamentals of Faith" teaches me to know more about Jesus Christ. (3.80)

With these results, the data shows that catechesis had a positive impact on the lives of the Grade 12 non-Catholics and non-Christian students at UST Senior High School for it helps them to value respect and camaraderie among other people in different religious beliefs. The respondents showed that the Catholic faith formation instils moral values that lead them to have good attitude or behavior. Lastly, through FunFaith, the students responded that they learned more about the life and ministry of Jesus Christ. On the other hand, the last three items with lowest computed mean, shows the least things that catechesis affect in their lives. These are the following:

$>\quad$ The subject "Fundamentals of Faith" guides me on how to express my faith in God. (3.43)

$>\quad$ The subject "Fundamentals of Faith" makes me feel that I belong even if I am not a Catholic. (3.40)

$>\quad$ The subject "Fundamentals of Faith" helps me improve my prayer or spiritual life. (3.26)

Although all these scores fall in the interpretation "strongly agree", it is still a sign that according to the respondents, catechesis through the subject "Fundamentals of Faith" needs to reinforce more when it comes to expressing one's faith in God on behalf of the non-Catholics and non-Christian students. Aside from this, the respondents also expressed that there is a need for a more inclusive atmosphere of learning the Catholic faith. Lastly, the result also shows that FunFaith must also strengthen the spiritual aspect of the learners through prayer life. In addition to these findings, the results of the qualitative part of the survey through open-ended survey questionnaire were also classified according to general or major themes and patterns in which the researcher identifies. Here is the summary of themes given by the respondents in each question:

Table 2

Results of question 1

Question \# 1: "What is your impression of a Catholic School?"

$50 \%$ of the respondents or 15 out of 30 respondents said that for them, a Catholic School is a school that is religious and strict in nature and conservative in education and proclaiming the faith.

$23 \%$ of the respondents or 7 out of 30 respondents said that for them a Catholic School is a school that instils good values and character formation to all learners.

23\% of the respondents or 7 out of 30 respondents said that for them a Catholic School is a school that offers catholic traditions and practices such as religion classes, sacraments, outreach programs etc.

$4 \%$ of the respondents or 1 out of 30 respondents said that a Catholic School is a school that respects other beliefs (non-Catholics etc.)

72 Consortia Academia Publishing (A partner of Network of Professional Researchers and Educators) 
It is clearly stated in this first data information that the respondents' impression of a Catholic School is an institution rooted in religious and strict observance Catholic faith through its rules and regulations. They also believe that a Catholic school inculcate in the minds and hearts of the student's good values and forms them to become better persons of character. Part of the mission of Catholic Schools is to proclaim the faith through its various traditions and practices such as the sacraments, outreach programs and religion classes such as FunFaith. Only 1 out of 30 respondents said that their impression of a Catholic School is that it respects other beliefs such as the non-Catholics and non-Christians.

\section{Table 3}

Results of question 2

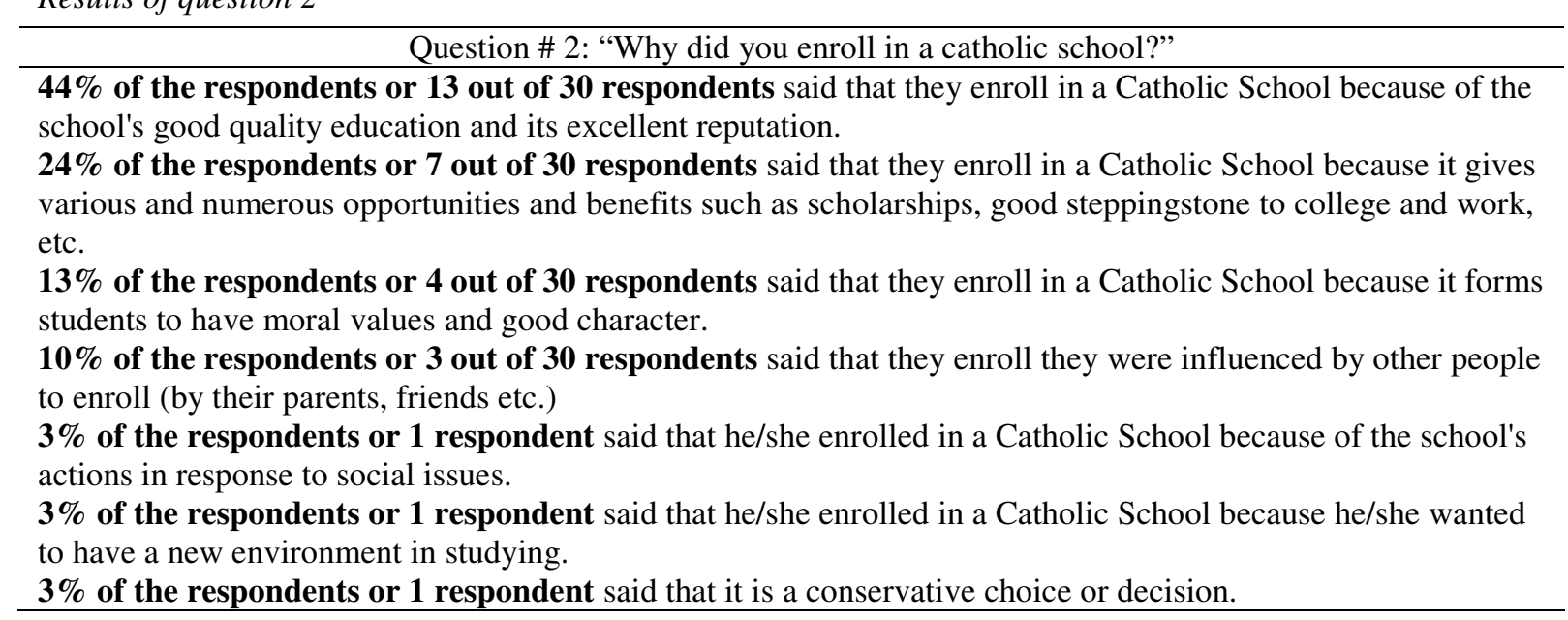

On this data, majority of the respondents said that they enrolled in a Catholic School for they believe in the good name of the school as well as its offering of excellent quality of education. Some of the respondents also mentioned that Catholic Schools offer a lot of opportunities and benefits for the students such as scholarships and good steppingstone for future and dreams in life. They also believe that Catholic Schools form students with good manners and values and its programs such as outreach activities motivates them to pursue and help other people. Other reason such as new environment and having this as a conservative decision also came out from the responses of the students.

\section{Table 4}

Results of question 3

Question \# 3: "What practices, actions and activities in Catholic School help you develop your faith?" $40 \%$ of the respondents or 12 out of 30 respondents said that prayer atmosphere and culture of the Catholic School developed their faith.

$17 \%$ of the respondents or 5 out of 30 respondents said that the celebration of the Mass developed their faith. $13 \%$ of the respondents or 4 out of 30 respondents said that through various religious practices and programs such as outreach programs developed their faith.

$13 \%$ of the respondents or 4 out of 30 respondents said that through FunFaith classes, they developed their faith in God.

$7 \%$ of the respondents or 2 out of 30 respondents said that through their FunFaith teachers, they developed their faith in God.

$7 \%$ of the respondents or 2 out of 30 respondents said none.

$3 \%$ of the respondents or 1 respondent said that through daily interactions with other people in the Catholic school developed his/her faith.

In this data, it is significant that for most of the respondents, the good prayer atmosphere in the University had an impact in their faith lives. Many of them highlighted the memorized prayers and the Angelus and 3'o clock prayer made them wonder about Catholic Schools for the people, no matter what they do, find time for God and stop on their doings and pray. The celebrations such as the Mass, the sacraments and outreach programs 
Quimson, L. O., Jr.

also are noteworthy in the faith formation of the students. Gonzales (2019) affirms in his study that "frequent celebration of the Mass as well as the good examples of faith of the faculty and their strong relations with their students make the non-Catholics and non-Christians have a good impression in Catholic Schools" (p. 40). Moreover, the respondents also mentioned that FunFaith classes, with the help and passion of the professors of FunFaith, helped them realize the importance of knowing and learning the faith. While some respondents also said that there is no significant impact with regards to the religious activities of the Catholic Schools in their faith life.

\section{Table 5}

Results of question 4

Question \# 4: "Does FunFaith had an impact in your faith life? Explain."

$37 \%$ of the respondents or 11 out of 30 respondents said that FunFaith has impact on imparting the existence and need for God in their lives.

$20 \%$ of the respondents or 6 out of 30 respondents said that FunFaith taught them to see the similarities and differences of their religion and learn respect in the Catholic faith.

$17 \%$ of the respondents or 5 out of 30 respondents said that FunFaith had an impact because of their passionate teachers and their way of teaching the faith.

$13 \%$ of the respondents or 4 out of 30 respondents said that FunFaith made them curious and taught them to know more the Catholic faith and its teachings.

$7 \%$ of the respondents or 2 out of 30 respondents said that FunFaith taught them that faith is also related to daily life and taught them to relate to other people.

3\% of the respondents or 1 respondent said that FunFaith helps him/her to be relieved from academic stress

$3 \%$ of the respondents or 1 respondent said that FunFaith influenced him/her through its content, as well as prayer and worship.

This data presents interesting information about FunFaith on how catechesis had impact or effect in the lives of the non-Catholics and non-Christian students. First, FunFaith helped them realize the existence and their thirst or need for God in their lives. Secondly, through this subject, they realized that there are still similarities amidst various religions aside from the Catholic faith. With this, they learned how to respect religious beliefs and cultivate understandings and relationships. Catechesis also became an avenue for the students to value their faith in God through the passion, enthusiasm, and dedication of their FunFaith teachers or professors. With this, they also became curious to know the faith and open their minds and hearts to dialogue. In addition, FunFaith also helped them cope on their stress in academics as well as it also helps them to relate the teachings of Christ and the Church in their daily living, in its content, prayer and faith response.

\section{Table 6}

Results of question 5

Question \# 5: "What are your suggestions in order for FunFaith to add meaning in your faith life?"

$33 \%$ of the respondents or 10 out of 30 respondents suggested relating FunFaith in real life situations to connect the faith in their lives and make it creative and engaging to the learners.

$20 \%$ of the respondents or 6 out of 30 respondents suggested to be inclusive and let students express their sentiments and side in the light of their faith.

$10 \%$ of the respondents or 3 out of 30 respondents suggested incorporating in the lessons the current social issues that the present generation faces in light with the faith.

$10 \%$ of the respondents or 3 out of 30 respondents said that FunFaith is already good as a subject and learning avenue in faith.

$10 \%$ of the respondents or 3 out of 30 respondents suggested that teachers of faith must be passionate in teaching the faith, not just as a work but a vocation.

$10 \%$ of the respondents or 3 out of 30 respondents said they have nothing to suggest.

$7 \%$ of the respondents or 2 out of 30 respondents suggested that FunFaith must also enhance the prayer life or personal time with God.

On the last question, the researcher found out that majority of the respondents suggested to relate FunFaith in real life situations for faith to be connected in their lives. They wanted to be engaged and make the lessons creative and interactive. Some of the respondents also desire that FunFaith must be more inclusive especially to

74 Consortia Academia Publishing (A partner of Network of Professional Researchers and Educators) 
the other religions and let them also express their beliefs in the light of understanding and respect. Some also suggested including social issues and current events that the present generation faces in relation to the teaching of the faith. Some respondents also expressed that the teachers of FunFaith must be more passionate in teaching the faith, not just doing it for the sake of work, for they feel in the hearts and zeal of teachers if they are truly inspired in proclaiming the faith and they have kept the flame of the Holy Spirit burning in their hearts. Lastly, the respondents also wanted to preserve prayer life in FunFaith classes. They wanted to include prayer spaces and time for God in prayer to deepen more their relationship with the divine, not just lecture and lesson discussions.

\section{Conclusion and recommendation}

After analyzing the data gathered, the researcher therefore concludes that Catechesis, through the subject Fundamentals of Faith or FunFaith had an impact in the lives of the selected Grade 12 STEM students at the UST Senior High School. The teaching of the Catholic faith helped them realize more the essence of God in their lives and open their minds and hearts to seek more God through knowing His story and teachings. Through FunFaith, they also learned to value respect among beliefs and open the opportunities of dialogue and understanding the Catholic faith for it has also similarities with their respective beliefs. Another impact of catechesis is that the FunFaith teachers are good in proclaiming and teaching the Christian faith which made the learners interesting in learning more the faith. Lastly, the teaching of the faith made them realize that it can also be connected and applied in their daily lives and help them also to relate with other people.

In addition, this study would like to recommend the following:

$>\quad$ The provision for an "Integral Approach" in teaching the faith spearheaded by the catechists and professors of Fundamentals of Faith which includes the integration of catechetical method in religious instruction, using varied strategies aside from lecture discussion, emphasizing the linkage or deepening of the human experiences or life situations of learners in connection with the faith and inculcation of the moral and worship dimensions of faith in the lessons.

$>\quad$ The possibility of having an "ongoing formation program" of the catechists with the support of the UST Senior High School Administration for the catechists to be updated in the latest trends in Religious Education and Catechesis, be informed on the current social issues in relation with the faith to address the signs of the times and needs of learners.

$>\quad$ A call for the catechists and religious educators to be more inclusive in discussing the faith and make the atmosphere of learning FunFaith ecumenical and feasible for recognition and respect for each belief.

$>\quad$ An opportunity to having "prayer spaces, events and avenues" for the non-Catholics and non-Christian students in the UST Senior High School and in every Catholic Schools to value fellowship and harmony with other beliefs and concretize the "catholicity" of our faith.

$>\quad$ The possibility for Fundamentals of Faith Department to have partnerships with the Pastoral Ministry or Community Extension Department or SIMBAHAYAN and the Center for Campus Ministry to craft formation programs for the students to make the teaching of the faith not just inside the four corners of the classroom but also possible through outreach activities and liturgical celebrations.

\section{References}

Acts and Decrees of the Second Plenary Council of the Philippines (PCP): Held at the Holy Apostles Seminary, Makati, Metro Manila from 20 January-17 February 1991. (1992). Manila: Paulines Publishing House.

Barron, R. (2006, January 22). The glory of God is a human being 'fully alive'. Retrieved from https://www.wordonfire.org/resources/article/the-glory-of-god-is-a-human-being-fully-alive/ 
Quimson, L. O., Jr.

Catechism of the Catholic Church (CCC). (1994). Manila: Word and Life Publications.

Catholic Bishops Conference of the Philippines (CBCP). (1997). Catechism for Filipino Catholics. Manila:

$\mathrm{CBCP}$.

Congrégation for the Clergy. (1997). General Directory for Catechesis: Vatican City: Libreria Editrice Vaticana.

Donlevy, J. K. (2007). Ten dimensions of inclusion: Non-Catholic students in Catholic Schools. Journal of Catholic Education, 10(3). Retrieved from http://digitalcommons.lmu.edu/ce/vol10/iss3/4 https://doi.org/10.15365/joce.1003042013

Gonzales, J. (2019). Sharing the gospel to non-Catholic learners. Momentum, 40-41. Retrieved from https://read.nxtbook.com/ncea/momentum/spring_2019/sharing_the_gospel_with_non_chtml

Groome, T. H. (2011). Will there be faith? A new vision for educating and growing disciples. New York, NY: HarperOne.

Hawker, J., \& Bowman, T. (1984). Non-Catholic in the Catholic school. Washington, DC: National Catholic Educational Association.

John Paul II. (1979). Catechesis in our time: Catechesi Tradendae. Boston, MA: Pauline Books and Media.

Message to the people of God and interventions of the U.S. delegates. (1978). Washington, DC: United States Catholic Conference.

Natividad, M. L. (2018). Teaching the faith: Renewal in religious education in the Philippines. Quezon City: Claretian Communications Foundation.

New National Catechetical Directory for the Philippines. (2007). Manila: Episcopal Commission on Catechesis and Catholic Education, Catholic Bishops Conference of the Philippines.

Ortiz, J. (n. d.). What is a Catechist? How to give Religious Instruction. Manila: Sinag-Tala Publishing Inc.

Peña, B. (1982). Catechetics: The proclamation of the soteriological message.

Roche, J. L. (2008). Practical Catechesis: The Christian faith as a way of life. Quezon City: Phoenix Publishing House.

Rymarz, R. (2011). Catechesis and religious education in Canadian Catholic Schools. Religious Education, 106, 537-549. https://doi.org/10.1080/00344087.2011.613355

Sacred Congregation for Catholic Education (1977). The Catholic school. Washington, DC: Catholic Conference.

Synod of Bishops. (1977). Fourth general assembly. Rome.

The New American Bible: Revised edition; translated from the original languages with critical use of all the ancient sources. (2015). Washington, DC: United States Conference of Catholic Bishops. 